\title{
Thew View from Where We Stand: Oral History and Expanded Horizons
}

\author{
Ronald J. Grele*
}

\section{Oral History and Archives}

Oral History in the United States had its origins in archival concerns and the practices of the publishing world. Worried that in the age of the telephone, and in an era when men of affairs no longer kept diaries or wrote their memoirs, the early founders of oral history, most notably Allan Nevins, Louis Starr, James Mink, Willa Baum, and others who gathered in 1967 to found the United States Oral History Association, argued that personal interviews, properly researched and processed, on file in manuscript collections and archives, would provide the basis for historical research and the publication of books by historians and others in the future. The goal of this effort was to complement the written record with information gleaned from interviews, and fill in the gaps in that record in the same manner that letters, journals and diaries had done since the dawn of widespread literacy. The final result according to Nevins, was to, "hold in view the publishable book". The implication was two fold, the publication of more books of history and the creation of the oral history document itself as a mirror to a book. It was to be transcribed, edited, indexed and archived as a book. In some cases, called a memoir, and in others edited as part of the process of transcription just as a publishable manuscript would be. Even in cases, such as Columbia, where editing by

* Columbia University. 
project staff was minimal, the date of submission (completion of the process), not the date of the interview, was the officially cataloged date of the interview, mimicking the world of publishing.

Given the accent upon filling in the gaps in the written record and the view of an oral history as something produced as part of a collection for an archive rather than as a historiographic act or a way of teaching history, it was not extraordinary that most of the earliest American oral history projects were situated in archives, libraries or manuscript collections, either private or governmental, rather than academic departments at major universities, and a great deal of attention was spent on questions of access, copyright, processing and cataloging.

In line with this goal of filling in the gaps in the written record it was assumed that the relationship between the interviewee and the interviewer would be one of professional distance, "objective" and contemplative. Since the interviewer was not to be the final user of the interviewer, simply an assistant in the creation of the record, his or her presence, either as interpreter or creator, would only be an intrusion on that relationship. Taking their cue from theorists in the social and behavioral sciences, who argued that it was imperative that the interviewer not bias the sample these early practitioners even worried that historians themselves were too involved in the questions under investigation and too driven by their own research agendas to be the best interviewers. To be sure Nevins and his colleagues recognized that the interviewee should be encouraged to express all of his or her passions and biases in recreating the emotions of the past; that was to be expected and even encouraged in order to get the best record - they were, after all, only facts of a different order - but the interviewer was there to be the outside and objective observer of the process and the judge of the usefulness of the interviewees interjections. In addition, the interviewer was the person who determined what was to be discussed in the interview because he or she had the best insight into what gaps had to be filled, but those decisions were to be made on the basis of what the record showed and what the profession considered worthwhile questions, not the values of the interviewer. In that way the interview would yield reliable and verifiable data, facts, information and interpretation, grounded in the best canons of research; data that the future historian could rely upon for his or her reconstructions. In short, the interview was a repository of information and the interviewee was seen as a source 
of that information. In some cases these early oral historians went so far as to describe their interviewees as sources.

The underlying assumption, of course, was that the truth of history rested in the facts, and that the collection and analysis of such facts would reveal that truth to the distanced and dedicated scholar.

This, in brief, in an age of empiricism and positivism, was the initial ideological structure of oral history in the United States. It had certain limitations and certain strengths. Firstly, this view assumed that the history to be recorded and studied was the history produced by those who left written records - generally those men and some women of power, or institutional affiliation. It was elitist to the core. Secondly, it sought to emulate the written record. A series of decisions were made on how to process the interview into a written transcript, edit it as one would edit a book or article, return the written transcript to the interviewee for further editing and then present it to the public as a book. In many of the early projects tapes were destroyed by reusing them, because it was felt that after the editing they would prove embarrassing to interviewees. In effect a conversation was transformed into a written document and the dialogical nature of the document was obscured or ignored.

Thirdly, the archival view of oral history relied on a narrow correlative theory of truth; what was useful in the interview was judged to be so by its relation to the written record. In this view, the interviewers held all power. Their questions, supposedly developed as a result of an "objective" view of the record determined the form of the interview and the final interpretation was that of the historian. If there was to be any interpretation by the interviewee, it was seen as either tentative (a first interpretation) or an intrusion on the recitation on the facts. The interviewer would determine the pace of the interview, what was included for discussion and what was rejected, where one began the story and what the narrative flow would be.

But there were also certain ways in which the archival stance enlarged the view of history in oral history. Firstly, and most importantly, the interview was meant to be a public record. It was to be placed in a depository where it would be consulted by generations of scholars, each generation bring to bear the concerns of that generation and thereby increasing the interpretative potential of the interview enormously. There was to be no source monopoly in oral history. Secondly, the view of men 
of affairs, or "movers and shakers" was fairly broad. It included leaders of labor unions, members of local elites, often those in the lower levels of the bureaucracy, notable women. Thus it was possible for projects mounted by local historical societies, local libraries, and smaller and more regional institutions to be regarded and legitimate sources of the practice. Both of these aspects democratized oral history in profound ways. In addition, following traditional and long established practices in the administration of archives and manuscript collections a great concern was shown for the allocation of literary rights and intellectual property. In this sense, power was restored to the interviewee as oral historians came to argue, in opposition to journalistic practice, that the words spoken did not belong to the archive for use by the public until they were formally donated by the interviewee.

\section{Transformations}

During the 1960s and 70s, oral history in the United States was transformed. The combination of the civil rights movement and the new social history led to an emphasis on the study of the lives and affairs of those who were not movers and shakers, a growing awareness of oral history efforts in other parts of the world led to the internationalization of the practice, the new left concern with subjectivity initiated what would become an almost epistemological break with the past, and more and more oral historians recognized the potential of the tape recording itself to become the basis of research and understanding.

There had long been a populist streak in American oral history work, especially that informed by the early interviewing efforts of the Works Projects Administration in the 1930s to collect reminiscences of former slaves and members of various American ethnic groups, or by projects in folklore. The enormous popularity of works by authors, such as Studs Terkel built on those traditions. The field was already plowed when the civil rights movement and the new social history raised the question of whose history one should study. More and more as the decade of the Sixties wore on there were calls for a new history; the history of African Americans, the history of heretofore ignored ethnic groups, the history of women, the history of the working class, in short a new 
history from below. If there were gaps in the historical record they were the gaps brought about by the fact that historian had long ignored these histories in their concentration upon the history of the powerful. In addition, it was argued, one found in the history of everyday life the true center of agency in social and cultural transformation and in thus in historical processes.

Looking abroad, especially to Europe, American oral historians found that this kind of interest and work was at the heart of oral history work. In both the United States and Great Britain the influence of the work of Edward Thompson and other social historians was central to this transformation. The publication of Paul Thompson's Voice of the Past seemed to capture the moment vividly. Informed by the new social history Thompson's book was, and remains, a clarion call for oral history as a history from below. It also represented the growing sense of an international movement, as Thompson, who organized the first of a series of international conferences that brought together workers in many fields from many nations, included in his work examples from around the world. The publication of the International Journal of Oral History in 1980 was in many ways the culmination of the ethos of that international community which was, many years later, institutionalized in International Oral History Association.

The creation of an international community and a new concern with social history did not necessarily mean a new way of viewing the oral history interview. Using the first edition of The Voice of the Past as a reference point one can easily see, despite the work's brilliance, how the new social history could very easily coexist with the epistemology behind the view of the interview as a repository of information upon which the historian will build his or her interpretations. Indeed, there was a way in which, at this moment, the inherent tensions in the practice of oral history revealed themselves in what Michael Frisch described as the tension between no history and more history. Looking at the populist rhetoric that accompanied much of the writing about the relationship between oral history and the new social history, Frisch found a tendency to argue that oral history offered a method of bypassing traditional historical practices and understandings to get the voice of the people directly, without interpretation. On the other hand it was argued that oral history offered more history, it was an opportunity to pile fact upon fact; to amass more 
and more data; more history. Neither view, argued Frisch, spoke to the potential of oral history to guide us in understanding consciousness and the ways in which historical narratives are constructed in the process of the interview.

By the late 70s, these were questions that were being asked by more and more historians using oral history or doing oral history. It was clear that the interview did uncover what happened in the past, but it was also clear that it told us much about the ways in which history lived on in memory and in the present, and about the ways in which the present informed a view of the past. What was the nature of the relationship between the past as expressed in the interview and the present in which the interview was being conducted? While the arguments over these questions has a very convoluted and complex history, in brief, these issues merged with the new left concern with questions of subjectivity, not only the subjective areas of mental life such as ideology, memory, consciousness, and myth expressed by both interviewer and interviewee in the interview, but also the question of how the subject is formed in history, and the structured and structuring nature of what had traditionally been called consciousness. Luisa Passerrini merged the fieldwork she was doing interviewing working class Italians in Turin with the questions of subjectivity as asked by Lukacs and Gramsci to understand the complicated interweaving of the work ethic and silences about the Fascist period in Italy, in order to understand worker acceptance of Fascism. Alessandro Portelli began to apply the concerns of narrative theory to the oral history interview. The Birmingham Popular Memory Group looked at work in oral history and, in direct confrontation with Thompson, called for a new way of using and theorizing about such materials to uncover popular memory. In my own work I tried to merge structuralism and the work of Louis Althusser to understand the interview as text. Work, organized around a set of similar concerns, was also being done by Elizabeth Tonkin, Lutz Neithammer, Phillipe Joutard, Dora Schwartzstein, Antonio Montenegro, José Carlos Sebe and Eugenia Meyer. Much of this work reached out to other disciplines for theory and practice, disciplines such as: sociology, anthropology and linguistics.

All of this produced a very lively and complicated mix. Recognizing the potential of oral history to radically alter the ways in which history was understood led some scholars to ask new questions about memory and 
consciousness, while others began to think of new ways to teach history and new ways to mobilize sound and the new media in that teaching. Others saw in oral history the potential for historical drama, or therapy. The inherent interdisciplinarity of the practice was evident.

\section{New Issues}

Two elements of this complicated mix of issues deserve special attention: the new view of the relationship between interviewer and interviewee, and the consequences of looking at oral history as text. In the first case, the new social historians were very concerned that those being interviewed be seen as agents of their own history, and that the oral history process be seen as democratic, and that the interviewer be seen as more than simply a gatherer of facts. While in some cases, this led to the populist situation described by Frisch, where some argued that the interview was a moment in consciousness raising and that the interviewer was an agent of this new consciousness, more usually it led to a realization that most people were perfectly capable of interpreting their own pasts, that they were more than simply repositories of facts for the historian to document, or exemplars of false consciousness. This meant that the interviewer was called upon to share authority, and authorship, in the interview. Thus it was increasingly difficult to maintain old views of the relationship between the two parties in the interview. Whether called a conversation or not, it was a small step to then recognize the dialogic nature of the interview and, in the words of Portelli, to see the interview as an experiment in equality. In a hermeneutic sense, the interview became an arena of the struggle for meaning where two different but equal views of the past events under discussion meet in an effort to understand one another. Historians understand the meaning of the past we investigate based upon our research, our reading, our bibliography. The people we talk to understand that past because they have lived through those events. Neither view is to be privileged. Neither is better than the other. They are equal but different. To understand the interview is to understand the dynamic tension between these two perspectives.

This is what drives the narrative of the text, and text has come to be what defines the oral history interview. When we say we are looking 
for the ways in which subjectivity defines the history we are collecting, we understand that in order to uncover that subjectivity we must investigate the hidden levels of discourse embedded in the narrative. To examine the unfolding of memory, the articulation of ideology etc., we must look at the interview as a text. We examine the interview as a set of structures with each element seen in relation to all of other elements, we merge the study of the social event of the interview itself, the language of both interviewer and interviewee, and the deeper imaginative structures that govern the flow of the narrative. In brief, this view of the interview has led oral historians to a new concern with narrative and storytelling and to a new concern with the nature of the meaning of evidence in the interview, and especially a concern with issues of memory. In the archival method of oral history questions of evidence were usually answered by reference to the ways in which the traditions of evidentiary logic had emerged in the profession, as an example one can look at Thompson's work again. Now, however, we are asked to understand certain textual considerations as evidence. What, for instance, can we say about metaphor as evidence? Can we be satisfied with some kind of a concept of narrative truth? How does the dialogic nature of the interview alter our notions of memory?

However, we are never satisfied with text alone. That text must always be recontextualized, in the past about which we are speaking and in the present from which we speak. What the text tells us are the questions that the past asked of itself as reflected in the answers to the questions that the present asks of that past. Because oral history moves from one to the other so easily it becomes the quintessential historiographical practice.

We are now at the frontiers. Let me let it rest at that, but let me also point out that these questions of text are vital because the next stage of the development of oral history is impossible without the idea of text and a sense of its dialogical creation. And here I mean the ways in which oral history is being expanded by those who are using it as a vital element in web based projects, digital education and distance learning. While mostly beyond my own ken, it is obvious from the last meeting of the United States Oral History association that the future of our work will be defined by the needs of the digital world. Many of us have tried to meld the best of the archival tradition with the needs of a more democratic history. Let us hope that we can, in the future, continue to try to merge the best of different traditions. 
Abstract: It has now been over 50 years since oral history emerged as an important method of historical representation. In that time the practice has changed from a narrow archival and empiricist mission to a way in which we can understand subjectivity in its broadest sense, and involve the public we serve in the creation of its own history. This has meant a new way to view the collection of first person narratives. In particular these changes have demanded a new more participatory view of the relationship of the interviewer and the interviewee and a concern with the testimony as text and narrative. Both hold incredible democratic promise for the profession at large. The question for the future is how we, as oral historians, can carry that democratic mission into the digital age.

Keywords: oral history; subjectivity; narrative.

\section{A vista de onde estamos: história oral e horizontes expandidos}

Resumo: Há mais de 50 anos desde que a história oral surgiu como um importante método de representação histórica. Neste período, a prática mudou de uma missão empírica e estritamente arquivística para um modo pelo qual podemos entender a subjetividade em seu sentido mais amplo, e envolver o público que servimos na criação de sua própria história. Isso significou uma nova forma de ver as coleções de narrativas em primeira pessoa. Em particular essas mudanças exigiram uma visão mais participativa da relação entre o entrevistador e o entrevistado, e uma preocupação com o testemunho como texto e narrativa, o que são incríveis promessas democráticas para a profissão. A questão para o futuro é como nós, como oralistas, podemos levar esta missão democrática à era digital.

Palavras-chave: história oral; subjetividade; narrativa. 

